\section{Preplant Cultivation Techniques and Planting Date Effects on White Clover Establishment into an Existing Cool-season Turfgrass Sward}

Bret Sparks, Gregg Munshaw ${ }^{\mathbf{1}}$, David Williams, and Michael Barrett Department of Plant and Soil Sciences, University of Kentucky, 1405 Veterans Drive, Lexington, KY 40546-0091

Jeffrey Beasley

School of Plant Environmental and Soil Sciences, Louisiana State University Agricultural Center, Baton Rouge, LA 70803

Paul Woosley

Department of Agriculture, Western Kentucky University, Bowling Green, KY 42101

Additional index words. Trifolium repens, Microclover, core aeration, scalping, vertical mowing

Abstract. Managed turfgrass species require frequent inputs to maintain an acceptable level of density and appearance. Among these inputs, the $\mathrm{N}$ supply is often the most limiting input in terms of growth and development of the turfgrass stand. However, $N$ fertilization has been linked to nonpoint source (NPS) pollution of groundwater and natural water bodies. White clover (WC), which would provide $\mathrm{N}$ in mixed turfgrass swards, could help reduce NPS pollution from $\mathrm{N}$ fertilization of turf. To test the feasibility of introducing WC into existing turf, a field study was designed to determine the best method of incorporating WC in mature stands of two cool-season grasses. Two varieties of WC, 'Dutch White' (DW), and 'Microclover' (MC), were sown $\left(24.4 \mathrm{~kg} \cdot \mathrm{ha}^{-1}\right)$ into existing stands of kentucky bluegrass (KBG) (Poa pratensis L.) and tall fescue (TF) (Festuca arundinacea Schreb.). Establishment techniques tested included core aeration (CA), scalping (SC), and vertical mowing (VM) compared with direct sowing into the turfgrass stand. Establishment treatments were performed in April, July, and October of 2012-13 to examine for any seasonal timing effect on establishment. No significant difference in plant numbers (individual clover plants per square meter) was found between WC varieties among planting dates and techniques. The SC treatment resulted in the highest individual clover plant numbers. However, turfgrass recovery was significantly slower from the SC treatment than all other treatments. The summer planting date yielded the highest WC plant numbers. Recovery of the turfgrass from all preplanting treatments was also highest at the spring and summer planting dates.

Lawns cover over 17 million acres in the United States (USEPA, 2012a). They offer an aesthetically pleasing environment shown to improve mental health, quality of life, and social harmony (Beard and Green, 1994). Although many homeowners manage turfgrasses solely for aesthetics, healthy turfgrass offers multiple benefits to the environment including carbon sequestration (Bandaranayake et al., 2003), temperature reductions in urban heat islands (Spronken-Smith et al., 2000), and enhanced water infiltration and erosion control (Krenitsky et al., 1998).

Over the past few decades, the home lawn care (HLC) industry has developed into a multibillion-dollar industry (Steinberg,

Received for publication 28 Oct. 2014. Accepted for publication 2 Mar. 2015.

${ }^{1}$ To whom reprint requests should be addressed; e-mailgcmunshaw@uky.edu. in the urban landscape (Arnold and Gibbons, 1996).

Nitrogen applied in highly soluble forms, such as the inorganic $\mathrm{N}$ form urea, and not immediately taken up by plants, can be lost by a variety of mechanisms. Nitrates in the soil solution have a high propensity to leach through the soil profile and to contaminate groundwater (Robertson and Groffman, 2007). Inorganic $N$ sources also contribute to the NPS pollution problem as a result of runoff due to irrigation or rainfall, which ultimately moves the $\mathrm{N}$ to local water bodies (Law et al., 2004). Excessive concentrations of $\mathrm{N}$ and $\mathrm{P}$ fertilizers can lead to eutrophication in water bodies, a process by which algae blooms hyper proliferate, die, and decompose creating hypoxic conditions and death of other aquatic organisms (Art, 1993). The USEPA has estimated that "NPS pollution is now the single largest cause for the deterioration of our nation's water quality" (Baird and Lawrence, 2006).

Increased NPS pollution concerns have led homeowners and lawn care operators to seek alternatives to inorganic fertilization and other inputs for maintaining lawns. One alternative to inorganic fertilizers is organic nitrogen derived from waste sources such as sewage sludge and bone meal (Law et al., 2004). Another option is to amend soil with organic compounds to improve the soil and plant health (McDonald, 1999). These organic materials, however, can have unpleasant odors and be difficult to handle and apply. Also, due to low $\mathrm{N}$ analyses, most organic compounds must be applied in such large amounts that they are not cost-effective and are, therefore, not a viable option compared with inorganic $\mathrm{N}$ sources. Furthermore, it has been shown that using organic fertilizers for reducing nitrate loss can lead to increased phosphorus levels, which are also associated with NPS pollution (Sharpley et al., 1994).

One possible alternative to inorganic $\mathrm{N}$ fertilization is the incorporation of legumes, such as WC, into turfgrass stands. Legumes fix atmospheric $\mathrm{N}$ and prior studies have reported fixation rates of between 23 and $187 \mathrm{~kg} \mathrm{~N} / \mathrm{ha} / \mathrm{yr}$ (Jørgensen et al., 1999; McCurdy et al., 2014), and even up to 545 $\mathrm{kg} \mathrm{N} / \mathrm{ha} / \mathrm{yr}$ (Elgersma and Hassink, 1997). Some recommended $\mathrm{N}$ fertilization rates for a moderately maintained KBG or TF lawn is 98-147 kg/ha/yr (Kopp and Guillard, 2002; Law et al., 2004; Munshaw, 2014). If even a portion of a lawn's yearly $\mathrm{N}$ needs can be supplied by WC, the reduction in fertilizer use could be significant and could reduce the amount of NPS related with the HLC industry.

'Dutch White' is a common variety of WC found in landscapes. It is an intermediate variety in terms of height and leaflet size. Like other WC varieties, it grows through proliferation of stolons that root at the nodes (Frame and Newbould, 1986). 'Microclover' is a recently released variety of WC selected to grow lower and produce smaller leaflets than other WC varieties (Heijden and Roulund, 2010), which allows it to mix well with traditional cool-season lawn grasses. 
Because very little has been published concerning the best ways to establish WC in mature cool-season turf stands, this study was designed to examine the effects of three preplanting cultivation techniques and planting dates on WC establishment in two existing cool-season turfgrass lawn settings. Establishing procedures for consistent, successful establishment of WC in existing turfgrass is essential if the introduction of WC is to be widely adopted by the industry. Part of this study aimed to determine the expected time for turf recovery following WC planting, as aesthetic quality is often a priority for lawn managers.

\section{Materials and Methods}

Inoculation of WC seed. Ten grams of DW and MC (both cultivars supplied by DLF-Pisckseed, Tangent, OR) seed were placed in separate plastic storage bins. Twenty-eight grams of Nitragin Gold Clover inoculant (Novozymes, Bagsvaerd, Denmark) (Rhizobium leguminosarum bv. trifolii) was mixed into a simple syrup solution (237 $\mathrm{mL} \mathrm{H}_{2} \mathrm{O}$ with $57 \mathrm{~g}$ of granulated sucrose) and then applied to the WC seed in plastic bins until seed was fully covered. This process was repeated before each WC planting and new WC seed was used each study year.

Establishment study. The establishment study was conducted at the University of Kentucky's A.J. Powell Turfgrass Research Center near Lexington, KY. The experimental design was a split-split plot design with three replications. This study was performed in mature swards of 'Lesco Blend' TF and 'New Glade' KBG. Before this study, plots had been maintained with 49-98 kg N/ha/yr and mowed at $7.6 \mathrm{~cm}$. The soil type was a Maury silt loam (fine, mixed, active, mesic typic Paleudalf) with a $\mathrm{pH}$ of 6.5. Individual plots measured $2.32 \mathrm{~m}^{2}$ and received one of four preplanting treatments at one of three planting times (spring, summer, or fall). The preplanting treatments included $\mathrm{CA}, \mathrm{SC}$, VM, or no treatment (NT). These treatments were chosen to represent operations with equipment accessible to many homeowners. Core aeration was performed with $1.25 \mathrm{~cm}$ hollow tines on $5 \mathrm{~cm}$ by $2.5 \mathrm{~cm}$ spacings at a depth of $5 \mathrm{~cm}$. Two passes were made in perpendicular directions. Scalping was performed using a rotary mower with one pass made across the plot to lower the height of the stand from 7.6 to $2.5 \mathrm{~cm}$. Vertical mowing was performed at a depth of $7.5 \mathrm{~mm}$ with $2.5 \mathrm{~cm}$ spacings in two perpendicular passes across the sward. Following the treatments, all clippings and debris were removed from the plots before seeding. Spring plantings were seeded on 12 Apr. 2012 and 16 Apr. 2013. Summer plantings were seeded on 19 July 2012 and 23 July 2013. Fall plantings were seeded on 18 Oct. 2012 and 22 Oct. 2013. Temperature data for each year is shown in Figure 1. Each plot was handseeded with $24.4 \mathrm{~kg}$ pure live seed (PLS) $/$ ha of DW or MC (Clark, 2007). Following seeding, the treatment area was raked with spring tooth rakes flipped over to increase seed-soil contact, and then irrigated as necessary with an overhead system to encourage WC establishment. No fertilizer was applied previous to or during this study.

Data collection. Following seeding, swards were rated for visual quality weekly for 6 weeks after treatment (WAT). Ratings were on a 1-9 scale, with one being bare soil and nine having equivalent visual quality to the NT plot. A clover population count was recorded at 6 WAT by randomly tossing a 10 $\mathrm{cm}$ diameter ring in each plot and counting WC leaves only. Population counts are reported based on number of individual clover plants per square meter.
Statistical analysis. Data were analyzed using the general linear model procedure with repeated measures for recovery ratings using SAS (SAS ${ }^{\circledR}$ Institute v. 9.3, Cary, NC). All means were separated using Fisher's protected least significant difference test at an alpha level equal to 0.05. Experiments within KBG and TF swards were considered separate due to the inability to randomize existing mature KBG and TF swards. Therefore, no statistical comparisons can be made between the two turfgrass species, even though similar trends were observed. For $\mathrm{KBG}$, results did not differ between years $(P=0.05)$ for either recovery ratings or WC population counts. This allowed data from

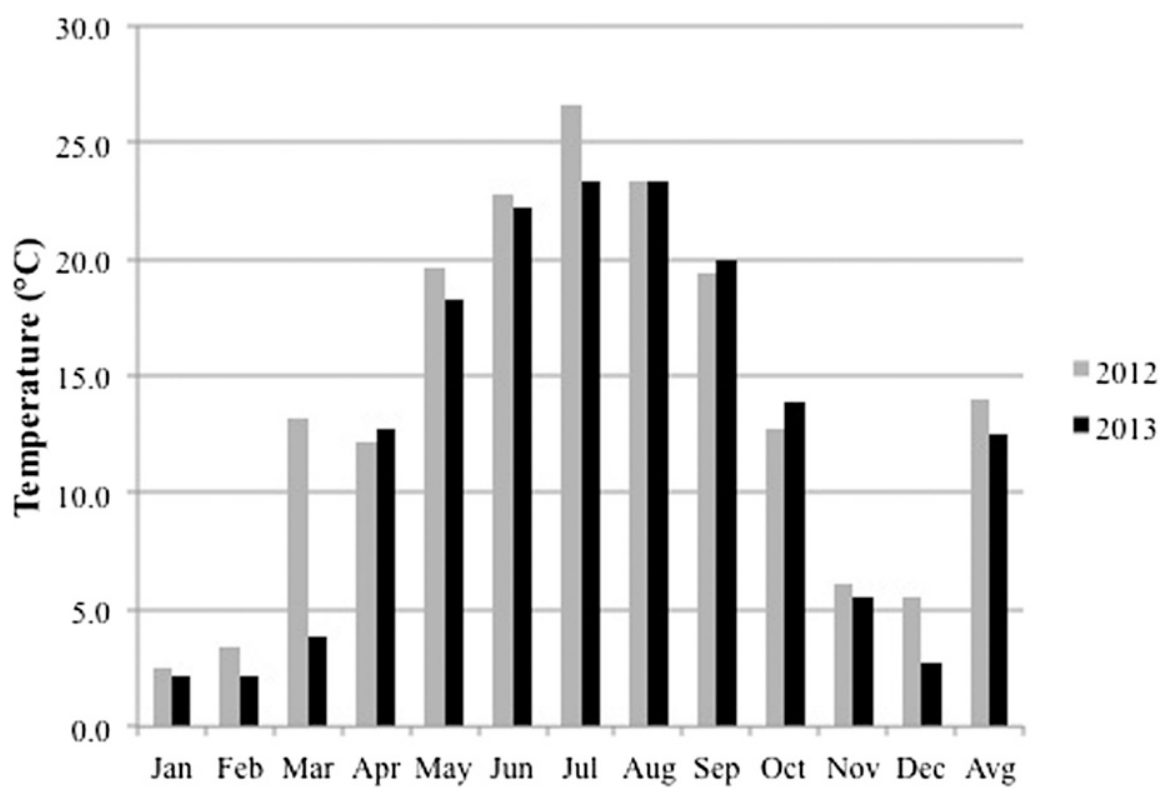

Fig. 1. Average monthly temperatures for Lexington, KY in 2012 and 2013. White clover was planted in April, July, and October.

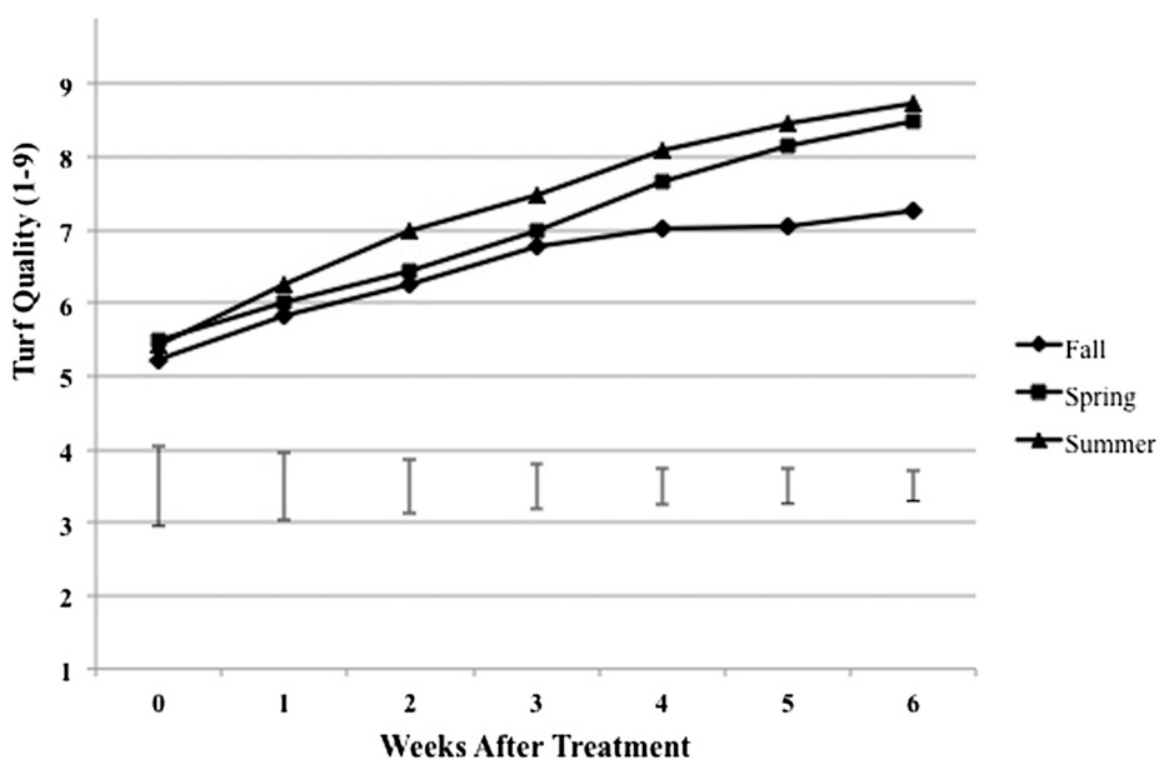

Fig. 2. Effect of planting date on kentucky bluegrass turf quality following preplant cultivation techniques averaged across years. Bars represent F-protected Fisher's least significant difference values $(P<0.05)$ for each evaluation date. 
2012 and 2013 to be pooled. In TF, no significant year main effects were detected for recovery ratings $(P=0.0622)$. However, significant differences were found between years for final clover population counts $(P=$ $0.0007)$ and, therefore, results are reported separately for each year. The difference in WC counts among years in TF is most likely due to the occurrence of brown patch (Rhizoctonia solani, Kühn) in TF stands during the summer of 2012. Additionally, no significant differences were found between DW and $\mathrm{MC}$ so data were combined and is reported across WC varieties for both turf species.

\section{Results and Discussion}

Planting dates. Planting treatments exhibited no differences in turf quality between planting dates the first 4 weeks post application (Figs. 2 and 3). However, recovery from planting treatments in fall was stymied by the onset of less than optimal temperatures. The optimum temperature range for cool-season turfgrass growth is 15.6 to $23.9{ }^{\circ} \mathrm{C}$ (Turgeon, 2011). In both years, Lexington's average temperatures for all three timings were below the optimum range at the time of initial cultivation (Fig. 1). For both spring and summer plantings, average temperatures entered the optimum range by 4 WAT and stayed in this range for the duration of the study. However, fall temperatures continued to decline further below the optimum range during the observation period, dropping $7{ }^{\circ} \mathrm{C}$ in 2012 and $8.5{ }^{\circ} \mathrm{C}$ in 2013 from initial ratings to 4 WAT. At 6 WAT, spring and summer still had significantly better recovery than the fall treatments in both KBG and TF. Suboptimal temperatures following fall plantings likely slowed turfgrass growth compared with that in the spring and summer planted plots and resulted in less recovery 5 and 6 WAT. Similar results have been shown in perennial ryegrass (Lolium perenne L.) where lower temperatures caused reduced stand recovery following intense canopy disruption (Alberda, 1957). Also, although spring is generally a favorable growing season for cool-season grasses, the summer environmental conditions in this study proved to be just as effective for providing ample recovery from cultivation techniques.

Individually, the fall CA swards exhibited adequate recovery due to the less injurious nature of the treatment as seen from initial damage ratings (data not shown). However, the severe damage associated with SC and VM treatments was significant enough to prevent the turfgrass swards from reaching a complete recovery. In fact, fall SC and VM plots did not reach complete recovery until April the following year. If fall establishment is to be considered using either SC or VM, then plantings should likely occur earlier in the season to avoid temperature fluctuations that would inhibit recovery. Dudeck and Peacock (1983) found September to be an ideal timing for WC germination in bermu- dagrass (Cynodon dactylon L.) stands in north Florida, whereas McCurdy et al. (2013) found October to be the best timing in Alabama, although establishment was only

performed in the months between October and February. Based on the results of this study, however, any fall WC seedings should occur before October, ideally with sufficient

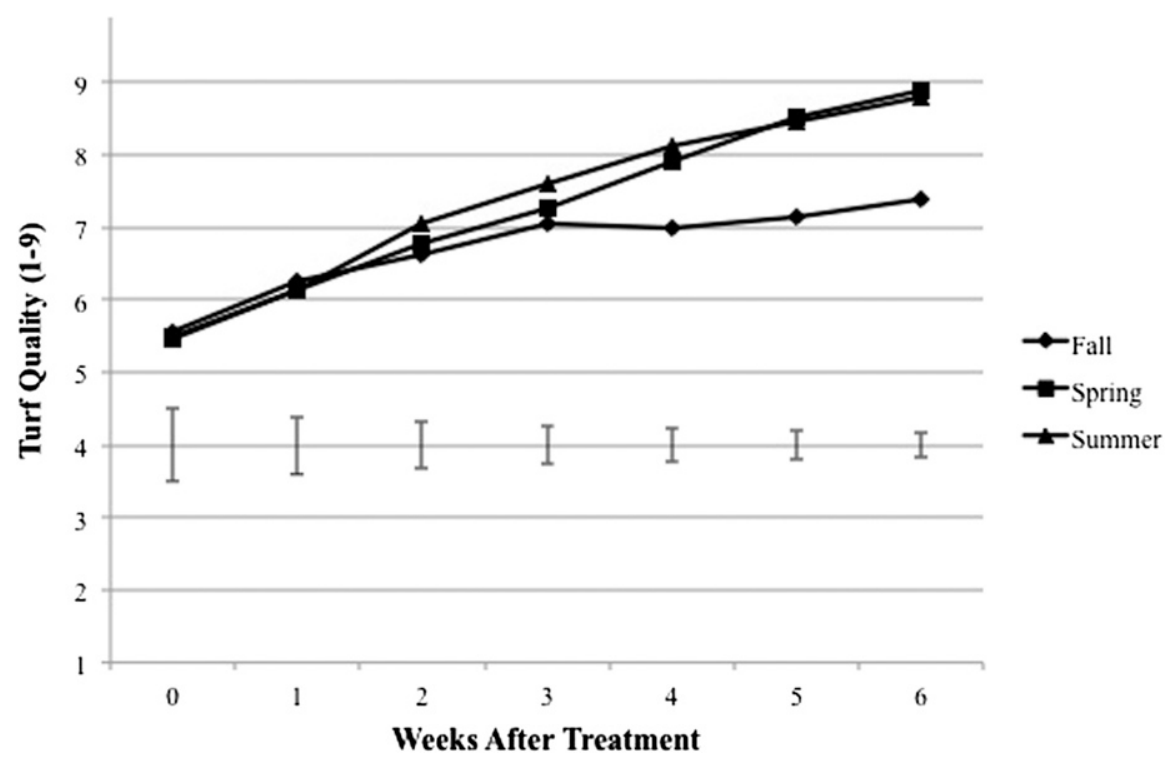

Fig. 3. Effect of planting date on tall fescue turf quality following preplant cultivation techniques averaged across years and preplanting treatments. Bars represent F-protected Fisher's least significant difference values $(P<0.05)$ for each evaluation date.

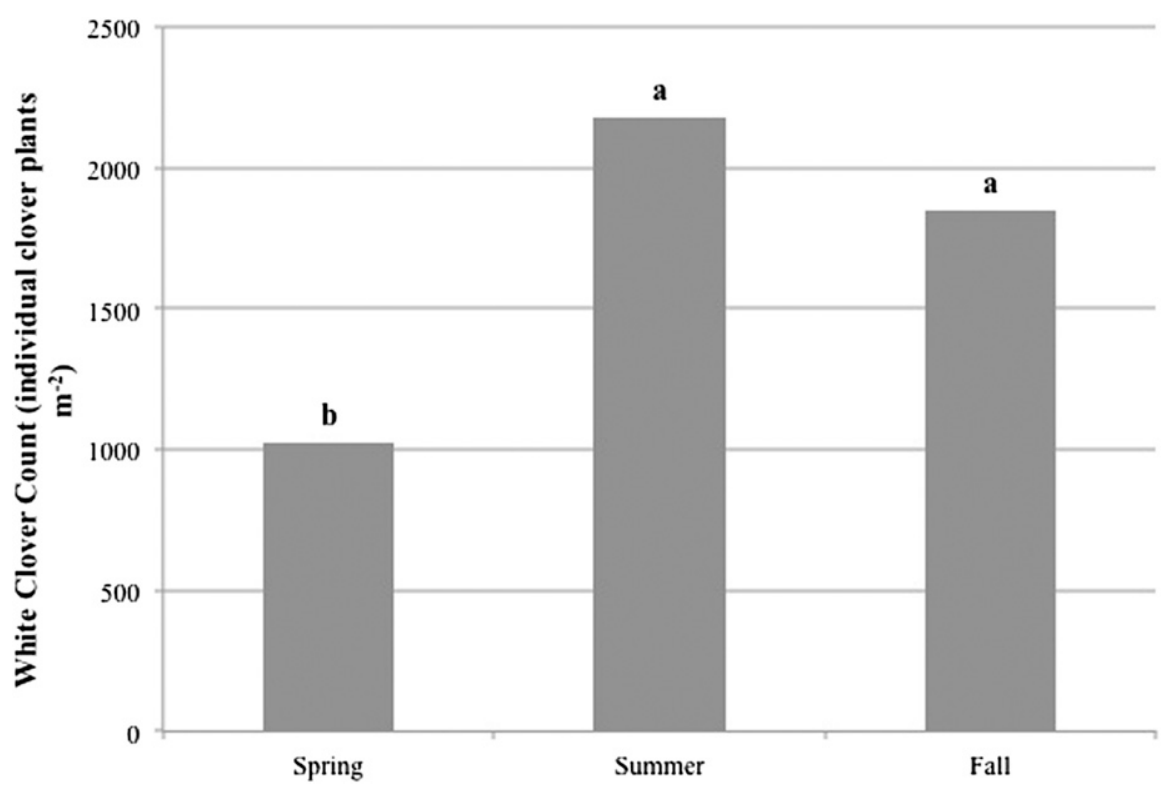

Fig. 4. Seasonal effect of planting on individual clover plants per square meter 6 weeks after treatment into kentucky bluegrass swards averaged across years. Different letters above bars represent significant difference at $P<0.05$.

Table 1. Effect of planting date on white clover counts 6 weeks after treatment in tall fescue swards averaged across all planting treatments.

\begin{tabular}{llc}
\hline Yr & Planting date & Plant counts (individual clover plants $/ \mathrm{m}^{2}$ ) \\
\hline 2012 & Spring & $807 \mathrm{~b}^{\mathrm{y}}$ \\
& Summer & $2,588 \mathrm{a}$ \\
2013 & Fall & $2,010 \mathrm{a}$ \\
& Spring & $533 \mathrm{~b}$ \\
& Summer & $1,267 \mathrm{a}$ \\
& Fall & $1,092 \mathrm{a}$ \\
\hline
\end{tabular}

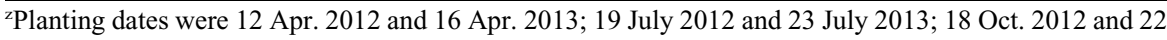
Oct. 2013; for spring, summer, and fall, respectively.

${ }^{y}$ Values followed by different letters within the same year are significantly different at $P<0.05$. 
time to allow a complete turf recovery before winter dormancy.

Summer and fall planting resulted in higher WC populations in KBG than spring (Fig. 4). The same was found for WC populations in TF (Table 1). Higher temperatures and longer photoperiods directly impact WC leaflet production and size, as well as stolon internode length (Boller and Nösberger, 1983). This would explain why summer planting consistently yielded the highest amount of WC plant counts in both $\mathrm{KBG}$ and $\mathrm{TF}$ stands, as the warmer temper- atures and longer days during summer promoted increased adventitious growth and leaf production. The optimum temperature range for WC germination is 20 to $30{ }^{\circ} \mathrm{C}$ (Moot et al., 2000). Hampton et al. (1987) reported delayed WC germination as temperatures decreased. Therefore, the slightly warmer temperatures in fall may have led to faster germination for the WC than in spring. Additionally, the slower turfgrass recovery in fall would have decreased the competition between KBG and TF with WC compared with that in spring and summer.

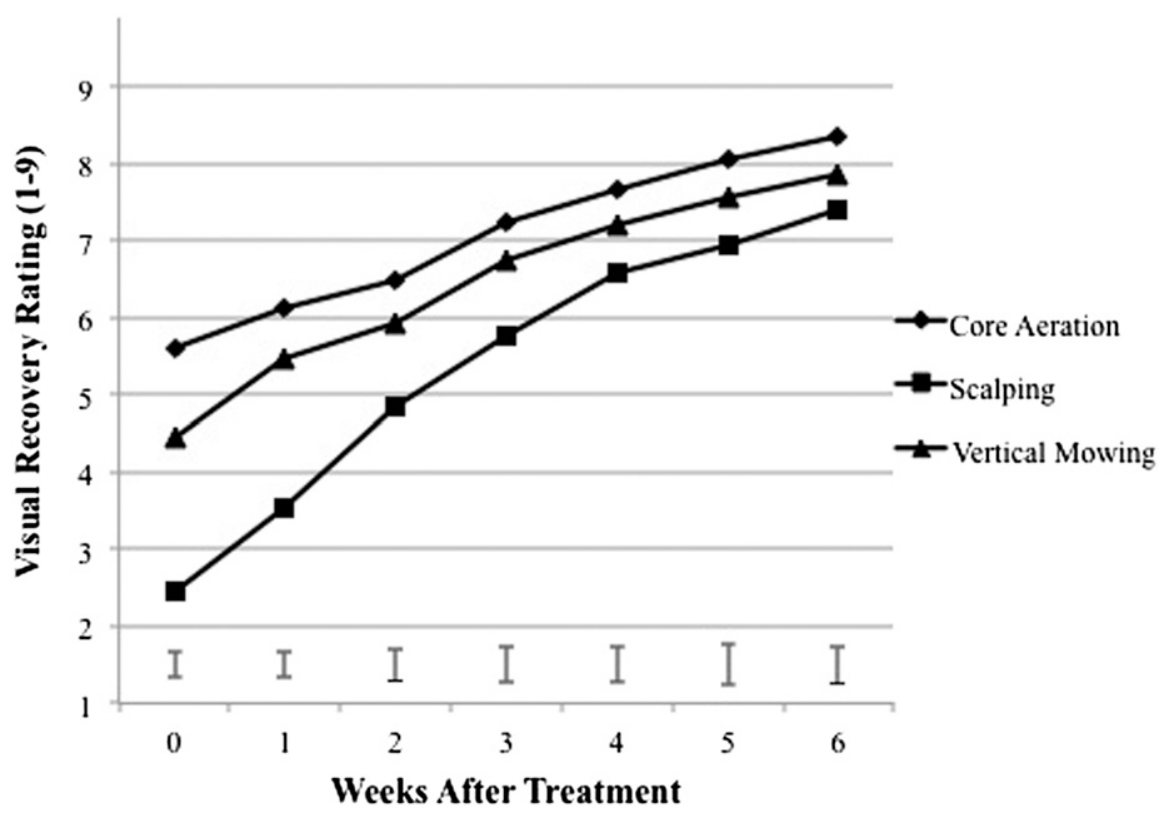

Fig. 5. Effect of preplant cultivation technique on kentucky bluegrass visual recovery rating averaged across years. Bars represent F-protected Fisher's least significant difference values $(P<0.05)$ for each evaluation date.

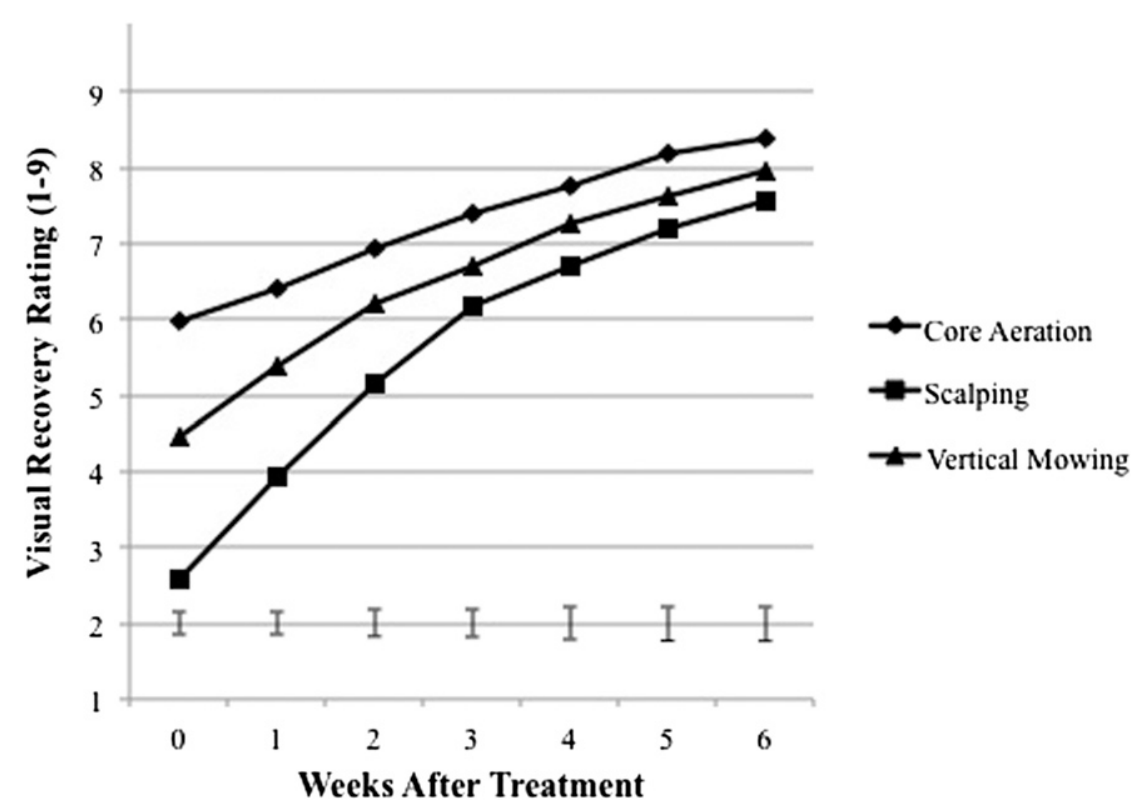

Fig. 6. Effect of preplant cultivation technique on tall fescue visual recovery rating averaged across years. Bars represent F-protected Fisher's least significant difference values $(P<0.05)$ for each evaluation date.

Preplanting treatments. When averaged across all planting dates, initial damage ratings in $\mathrm{KBG}$ and $\mathrm{TF}$ were in the following order: $\mathrm{CA}<\mathrm{VM}<\mathrm{SC}$ (Figs. 5 and 6). Carrow et al. (1987) reported that shoot density of bermudagrass (Cynodon dactylon L.) after initial cultivation was not different between CA once a year and NT. In our study, we found that, although there was some initial damage, turf in the CA treatment had acceptable quality $(\geq 6)$ by 1 WAT. Turf in the VM and SC treatments did not have an acceptable level of quality until 3 and 4 WAT, respectively. At $6 \mathrm{WAT}, \mathrm{SC}$, and VM produced equivalent turf quality, but $\mathrm{CA}$ had higher turf quality than both. Watschke and Waddington (1975) also found that KBG took longer to recover following damage from SC compared with CA and VM. Although SC caused the most damage, turf in all the SC plots were well above acceptable quality by 6 WAT in both turfgrass stands for the spring and summer planting dates.

In $\mathrm{KBG}, \mathrm{SC}$ resulted in the highest clover counts of any treatment, followed by VM, CA, and NT (Fig. 7). Similar results were seen for both years in TF (Table 2). The majority of initial damage caused by SC and VM was due to the removal of canopy. Scalping resulted in an especially high amount of canopy disruption, which most likely increased seed-soil contact and sunlight penetration to the WC seeds. Setterfield et al. (2005) showed that increased sunlight from canopy disruption leads to higher WC germination percentages. Additionally, reduced turfgrass canopy can also increase production of legume stolons (Ballaré et al., 1995). McCurdy et al. (2013) reported similar results in bermudagrass, where SC produced much higher WC germination than nonscalping treatments. While CA, on average, did not lower turf quality below an acceptable level, it also did not provide as favorable of an environment for WC germination and establishment as SC and VM. White clover populations in CA plots were significantly lower than SC and VM. This was likely due to the relatively low amount of canopy disruption by $\mathrm{CA}$ when compared with the other two treatments.

\section{Conclusions}

It will require a change in the aesthetic expectations of homeowners and turfgrass managers to move from monoculture stands of KBG or TF to mixed swards that include WC. However, the potential environmental benefit of such a change cannot be understated. Using smaller stature WC varieties that blend into the turfgrass sward could help increase acceptance of WC interseeding. Our results show that establishing WC in a mature stand of cool-season grass can be successfully accomplished in the spring and summer with equipment commonly available to homeowners. However, the best WC establishment was in SC plots, and this preplanting treatment is likely the only one of those tested that would result in enough WC cover to 


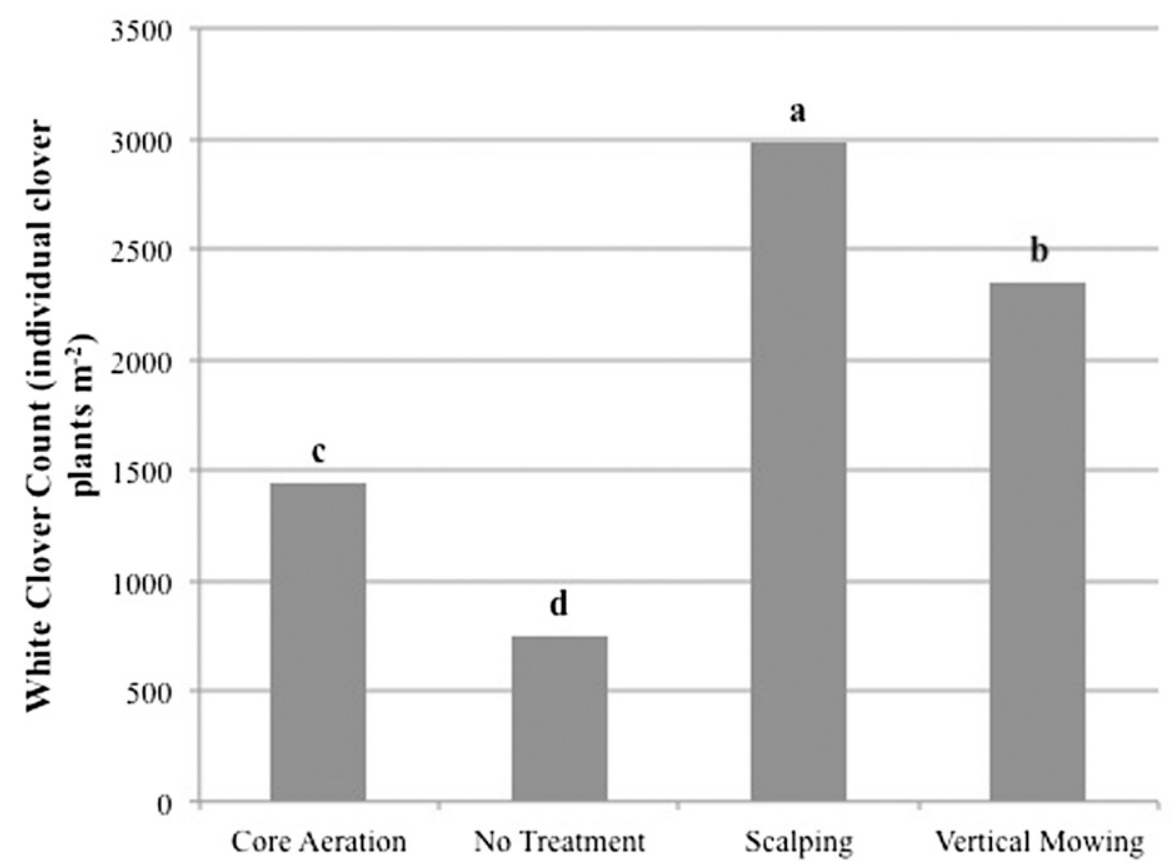

Fig. 7. Effect of preplant cultivation technique on individual clover plants per square meter 6 weeks after treatment in kentucky bluegrass (2012-13). Different letters above bars represent significant difference at $P<0.05$.

Table 2. Effect of preplanting treatments on white clover counts 6 weeks after treatment in tall fescue swards averaged across all planting dates.

\begin{tabular}{llc}
\hline $\mathrm{Yr}$ & Planting treatment & Plant counts (individual clover plants $/ \mathrm{m}^{2}$ ) \\
\hline 2012 & Core aeration & $1,410 \mathrm{c}^{\mathrm{z}}$ \\
& Scalping & $2,959 \mathrm{a}$ \\
& No treatment & $533 \mathrm{~d}$ \\
& Vertical mowing & $2,302 \mathrm{~b}$ \\
& Core aeration & $718 \mathrm{c}$ \\
& Scalping & $1,737 \mathrm{a}$ \\
& No treatment & $219 \mathrm{~d}$ \\
& Vertical mowing & $1,178 \mathrm{~b}$ \\
\hline
\end{tabular}

${ }^{\mathrm{z}}$ Values followed by different letters within the same year are significantly different at $P<0.05$.

reduce $\mathrm{N}$ inputs in a home lawn setting. Further testing is required to establish the WC population needed to reduce $N$ inputs. However, a recent study by McCurdy et al. (2014) showed that DW WC planted at $15 \mathrm{~kg}$ PLS/ha resulted in an estimated $66 \mathrm{~kg} \mathrm{~N} / \mathrm{ha} /$ $\mathrm{yr}$. If $\mathrm{N}$ fixation rates are similar between these two studies, we can estimate that $107 \mathrm{~kg}$ $\mathrm{N} /$ ha may be fixed with a seeding rate of 24.4 $\mathrm{kg} \cdot \mathrm{ha}^{-1}$. This amount of $\mathrm{N}$, if $100 \%$ available, would be sufficient for sustaining $\mathrm{TF}$ and KBG lawns (Kopp and Guillard, 2002; Law et al., 2004; Munshaw, 2014). Additional studies should also examine the effects of seeding rate on WC establishment. It is safe to assume that any amount of WC established in a turf sward should result in increased organic $\mathrm{N}$ levels and reductions in nutrient pollution due to a reduced need for inorganic $\mathrm{N}$ applications.

\section{Literature Cited}

Alberda, T. 1957. The effect of cutting, light intensity, and night temperature on growth tural carbohydrate concentration of two white clover ecotypes. Crop Sci. 23:1057-1062.

Carrow, R.N., B.J. Johnson, and R.E. Burns. 1987. Thatch and quality of Tifway bermudagrass turf in relation to fertility and cultivation. Agron. J. 79:524-530.

Clark, A. 2007. Managing cover crops profitably. 3rd ed. Sustainable Agriculture Network, Beltsville, MD.

Dudeck, A. and C. Peacock. 1983. Rate, method, and time of over-seeding white clover on bermudagrass during the winter. Proc. Fla. State Hort. Soc. 96:159-161.

Elgersma, A. and J. Hassink. 1997. Effects of white clover (Trifolium repens L.) on plant and soil nitrogen and soil organic matter in mixtures with perennial ryegrass (Lolium perenne L.). Plant Soil 197:177-186.

Frame, J. and P. Newbould. 1986. Agronomy of white clover. Adv. Agron. 40:1-88.

Hampton, J.G., J.F.L. Charlton, D.D. Bell, and D.J. Scott. 1987. Temperature effects on the germination of herbage legumes in New Zealand. Proc. NZ Grassl. Assoc. 48:177-183.

Harris, E.M., D.G. Martin, C. Polsky, L. Denhardt, and A. Nehring. 2013. Beyond "Lawn People": The role of emotions in suburban yard management practices. Prof. Geogr. 65:345-361.

Jørgensen, F.V., E.S. Jensen, and J.K. Schjoerring. 1999. Dinitrogen fixation in white clover grown in pure stand and mixture with ryegrass estimated by the immobilized ${ }^{15} \mathrm{~N}$ isotope dilution method. Plant Soil 208:293-305.

Kopp, K.L. and K. Guillard. 2002. Clipping management and nitrogen fertilization of turfgrass. Crop Sci. 42:1225-1231.

Krenitsky, E., M. Carroll, R. Hill, and J. Krouse. 1998. Runoff and sediment losses from natural and man-made erosion control materials. Crop Sci. 38:1042-1046.

Law, N., L. Band, and M. Grove. 2004. Nitrogen input from residential lawn care practices in suburban watersheds in Baltimore County, MD. J. Environ. Plann. Mgt. 47:737-755.

McCurdy, J.D., J.S. McElroy, and E.A. Guertal. 2013. White clover (Trifolium repens L.) establishment within dormant bermudagrass turf: Cultural considerations, establishment timing, seeding rate, and cool-season companion grass species. HortScience 48:15561561.

McCurdy, J.D., J.S. McElroy, E.A. Guertal, and C. W. Wood. 2014. White clover inclusion within a bermudagrass lawn: Effects of supplemental nitrogen on botanical composition and nitrogen cycling. Crop Sci. 54:1796-1803.

McDonald, D.K. 1999. Ecologically sound lawn care for the pacific northwest: Findings from the scientific literature and recommendations from turf professionals, p. 79. In: David, K. (ed.). Recommendations for the City of Seattle, WA.

Moot, D.J., W.R. Scott, A.M. Roy, and A.C. Nicholls. 2000. Base temperature and thermal time requirements for germination and emergence of temperate pasture species. New Zeal. J. Agr. Res. 43:15-25.

Munshaw, G. 2014. Fertilizing your lawn. Kentucky Cooperative Extension Service. Univ. Ky. Coop. Ext. Serv. Bul. AGR-212.

Robertson, G. and P. Groffman. 2007. Nitrogen transformations. Soil Microbiol. Ecol. Biochem. 3:341-364.

Setterfield, S., M. Douglas, L. Hutley, and M. Welch. 2005. Effects of canopy cover and ground disturbance on establishment of an invasive grass in an Australia savanna. Biotropica 37:25-31.

Sharpley, A.N., S. Chapra, R. Wedepohl, J. Sims, T.C. Daniel, and K. Reddy. 1994. Managing 
agricultural phosphorus for protection of surface waters: Issues and options. J. Environ. Qual. 23:437-451.

Spronken-Smith, R.A., T.R. Oke, and W.P. Lowry. 2000. Advection and the surface energy balance across an irrigated urban park. Intl. J. Climatol. 20:1033-1047.

Steinberg, T. 2006. American green: The obsessive quest for the perfect lawn. W.W. Norton \& Co., New York, NY.

Turgeon, A.J. 2011. Turfgrass management. 9th ed. Prentice-Hall, Englewood Cliffs, NJ.
Turner, T.R. and N.W. Hummel, Jr. 1992. Nutritional requirements and fertilization. In: Waddington, D.V., R.N. Carrow, and R.C. Shearman (eds.). Turfgrass (Agronomy). ASA, CSSA, SSSA, Inc., Madison, WI.

United States Environmental Protection Agency (USEPA). 2012a. Healthy yards, healthy lawns, healthy environment. 4 Oct. 2014. $<$ http://www.epa.gov/reg3wcmd/pesticideslawn.htm $>$.

United States Environmental Protection Agency (USEPA). 2012b. What is nonpoint source pollution? In: EPA Water: Polluted runoff. 10 Dec. 2012. <http://water.epa.gov/polwaste/ nps/whatis.cfm $>$.

van der Heijden, S.A.G. and N. Roulund. 2010. Genetic gain in agronomic value of forage crops and turf: A review, p. 247-260. In: Huyghe, C. (ed.). Sustainable use of genetic diversity in forage and turf breeding. Springer, London, UK.

Watschke, T. and D. Waddington. 1975. Effect of nitrogen fertilization on the recovery of 'Merion' Kentucky bluegrass from scalping and wilting. Agron. J. 67:559-563. 